\title{
Heat stress impact on blood biochemical response and plasma aldosterone level in three different indigenous goat breeds
}

\author{
Joy Aleena - Veerasamy Sejian (D). Govindan Krishnan - Madiajagan Bagath • Prathap Pragna • Raghavendra Bhatta
}

\author{
J Aleena ${ }^{\mathrm{A}, \mathrm{B}, \mathrm{C}}$ - V Sejian ${ }^{\mathrm{A}}$ (Corresponding author) -

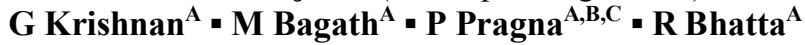 \\ ${ }^{A}$ ICAR-National Institute of Animal Nutrition and Physiology, \\ Adugodi, Bangalore, India.
}

email: drsejian@gmail.com
${ }^{B}$ Academy of Climate Change Education and Research, Kerala Agricultural University, Vellanikkara, Thrissur, Kerala, India.

${ }^{\mathrm{C}}$ School of Agriculture and Food, Faculty of Veterinary and Agricultural Sciences Dookie Campus, Dookie College, The University of Melbourne, Victoria 3647, Australia.

Received: June 27, 2020 • Accepted: July 18, 2020 • Published Online: July 27, 2020

Abstract A study was conducted to compare the adaptive ability of three indigenous goat breeds (Osmanabadi, Malabari, and Salem Black) to heat stress. The primary objective of the study was to assess the thermo-tolerant ability of these breeds to heat stress based on the changes in their blood biochemical response and aldosterone concentration. Thirty six-ten months to one year old female goats were randomly allocated into six groups of six animals each as OCON ( $n=6$; Osmanabadi control), OHS ( $n=6$; Osmanabadi heat stress), MCON ( $n=6$; Malabari control), MHS ( $n=6$; Malabari heat stress), SCON ( $n=6$; Salem Black control) and SHS ( $n=6$; Salem Black heat stress). The OCON, MCON, and SCON animals were maintained in the shed while OHS, MHS, and SHS animals were exposed to summer heat stress between 10:00 $\mathrm{h}$ to $16: 00 \mathrm{~h}$. All the animals had access to ad-libitum feed and water. The duration of the study was 45 days. The results indicated that breed differences $(P<0.01)$ were established for the levels of plasma glucose, total protein, albumin, and globulin. However, heat stress treatment did not influence these variables. Further, heat stress significantly increased $(P<0.05)$ plasma cholesterol only in the MHS group. Besides, albumin/globulin $(\mathrm{A} / \mathrm{G})$ ratio, plasma urea, and plasma urea nitrogen (PUN) did not show any significant variation both among and within the breed for the treatment. However, plasma triglyceride was significantly lower $(P<$ 0.05 ) in both OHS and SHS groups as compared to their respective control groups. Further, aspartate aminotransferase (AST) showed significant variation for the breed $(P<0.05)$ as well as treatment $(P<0.05)$ with a higher concentration in the OHS group. Among the breeds, heat stress induced lower $(P$ $<0.05)$ plasma aldosterone was established only in the MHS group. Thus, it can be concluded from the results that the Malabari breed which was well known for its survival in a harsh environment in its native tract could not adapt well to the new locality with a much lower magnitude of heat stress. However, Salem Black breed could exhibit superior adaptability to the new agro-ecological zone which was comparable to that of local Osmanabadi breed.

Keywords: adaptation, Capra hircus, climate resilience, indigenous breed, thermo-tolerance

\section{Introduction}

Livestock rearing serves as a major economic activity in the lives and livelihoods of millions of poor and marginal farmers, particularly in developing countries (FAO 2015). As per recent reports, livestock is considered as one of the fastest emerging dominant agricultural subsectors in the world (Thornton 2010). However, the productivity of the animal is observed to be conserved in a narrow range of environmental conditions (Baumgard and Rhoads 2013). Among the various climatic variables, ambient temperature fluctuations are found to be the most intriguing factor affecting livestock production potential (Sejian et al 2013). Prolonged exposures of the animals to heat stress conditions negatively affect their productive parameters such as growth, milk, meat, and reproduction, which in turn results in lower food production and higher economic loss to poor farmers (Rojas-Downing et al 2017).

Goat rearing acts as a critical source of income and nutrition for poor and marginal farmers in rural areas (Mlambo and Mapiye 2015). Recent statistics established significantly increasing the goat population throughout the world particularly in the poor countries (FAO 2015). Further, goats are also proved to have high thermo-tolerance capacity compared to all other livestock species and are observed to be widely distributed throughout the world even in regions having extreme harsh climatic conditions (Silanikove and 
Koluman 2015). Comparatively low body size and relatively low feed and water requirements enable them to thrive well during feed and water scarcity periods. Goats also possess a better feed conversion ratio than other ruminants and can convert low quality feed into quality protein (Silanikove and Koluman 2015). Therefore, these various unique characteristics of goat species specifically confirm their extreme potential to be considered as the ideal future animal to reduce the impacts of climate change in animal agriculture.

Performance of the livestock is influenced by several factors including the type of production systems, breed, age, sex, nutritional level, hormonal status, and environment (Habibu et al 2016). The agro-ecological zone as described by temperature, rainfall, topography, and vegetation is found to be a significant source of variation for animal production (Mpofu et al 2017). Livestock having superior productive traits may produce poorly when the production environment is not favorable due to negative interaction between their genetic merit and environmental variables (Mpofu et al 2017). In most cases, the shifting of exotic breeds from their specific agro-ecological zone failed to become a sustainable strategy mainly due to their compromised production levels in the new region. Hence, the identification of agro-ecological zonespecific breeds is considered an important strategy to sustain animal production levels optimally in the changing climate scenario. Therefore, the present study was conducted to evaluate the effect of shifting two extremely adapted indigenous breeds in their native tract to another agroecological zone and assess their adaptive capabilities in the new locality in comparison to the local breed. For this purpose, Malabari and Salem Black breeds are the two breeds well known for their ability to survive in extremely hot and humid environments were shifted to a new locality where the heat stress was of much lower magnitude. Their thermo-tolerance ability was compared to the local Osmanabadi breed well known for its survival in the current experimental location. With this background, the study was conducted with the primary objective to assess the differences in thermo-tolerance abilities of three different indigenous goat breeds based on blood biochemical response and aldosterone concentration.

\section{Materials and Methods}

\section{Location}

The experiment was carried out at the National Institute of Animal Nutrition and Physiology experimental livestock farm, Bengaluru, India which is located in the southern Deccan plateau of the country, located between approximately $12^{\circ} 58^{\prime} \mathrm{N}$ latitude and $77^{\circ} 38^{\prime} \mathrm{E}$, at an altitude of $920 \mathrm{~m}$ above mean sea level. The mean annual ambient temperature and relative humidity range from 15 to $36^{\circ} \mathrm{C}$ and 20 to 85 percent respectively. The annual rainfall in this area ranges from 200 to $970 \mathrm{~mm}$ with an erratic distribution throughout the year. The experiment was conducted during the summer season (April-May). The average meteorological data for the entire study period both inside the shed as well as outside are given in Table 1 and Figure 1 describes the respective temperature-humidity index (THI) values. The THI values were calculated as per the method described by McDowell (1972). Accordingly the formula used was THI = $0.72\left(\mathrm{~T}_{\mathrm{db}}+\mathrm{T}_{\mathrm{wb}}\right)+40.6$ where, $\mathrm{T}_{\mathrm{db}}=$ Dry bulb temperature in ${ }^{\circ} \mathrm{C} ; \mathrm{T}_{\mathrm{wb}}=$ Wet bulb temperature in ${ }^{\circ} \mathrm{C}$.

\section{Animals}

The study was conducted in 36 ten months to one-yearold female goats equally distributed into Osmanabadi, Malabari, and Salem Black breeds weighing between 12-19 $\mathrm{kg}$. Osmanabadi is a dual-purpose (meat and milk) hardy goat breed in the semi-arid areas of central tropical India. The breed received its name from its habitat and is observed to be distributed in areas of Ahmednagar, Solapur, and Osmanabad districts in Maharashtra (Deokar et al 2006). The goats are large in size. Coat color is predominantly black color (73 percent) and few individuals are white, brown, or spotted. The average body weights of adult male and female animals are 34 $\mathrm{kg}$ and $30 \mathrm{~kg}$ respectively.

Table 1 Average weather parameters both inside and outside the shed for entire study period.

\begin{tabular}{|c|c|c|c|c|c|c|c|c|}
\hline & $\begin{array}{l}\text { Time of } \\
\text { Recording }\end{array}$ & $\begin{array}{l}\text { DBT } \\
\left({ }^{\circ} \mathrm{C}\right)\end{array}$ & $\begin{array}{l}\text { WBT } \\
\left({ }^{\circ} \mathrm{C}\right)\end{array}$ & $\begin{array}{c}\text { MaxT } \\
\left({ }^{\circ} \mathrm{C}\right)\end{array}$ & $\begin{array}{c}\text { MinT } \\
\left({ }^{\circ} \mathrm{C}\right)\end{array}$ & $\begin{array}{l}\mathrm{RH} \\
(\%)\end{array}$ & $\begin{array}{l}\text { AT } \\
\left({ }^{\circ} \mathrm{C}\right)\end{array}$ & $\begin{array}{l}\text { PST } \\
\left({ }^{\circ} \mathrm{C}\right)\end{array}$ \\
\hline \multirow[t]{2}{*}{ Inside } & $\begin{array}{l}\text { Morning } \\
(8: 00 \mathrm{~h})\end{array}$ & $23.2 \pm 0.11$ & $17.5 \pm 0.17$ & $41.5 \pm 1.40$ & $22.5 \pm 0.92$ & $56.7 \pm 1.76$ & $26.6 \pm 0.31$ & $25.5 \pm 0.20$ \\
\hline & $\begin{array}{l}\text { Afternoon } \\
(14: 00 \mathrm{~h})\end{array}$ & $26.0 \pm 0.16$ & $21.6 \pm 0.15$ & $44.6 \pm 0.94$ & $24.1 \pm 1.02$ & $37.1 \pm 1.62$ & $34.2 \pm 0.22$ & $30.6 \pm 0.46$ \\
\hline \multirow[t]{2}{*}{ Outside } & $\begin{array}{l}\text { Morning } \\
(8: 00 \mathrm{~h})\end{array}$ & $24.5 \pm 0.55$ & $21.2 \pm 0.30$ & $44.0 \pm 1.27$ & $23.0 \pm 0.93$ & $58.6 \pm 2.54$ & $28.8 \pm 0.61$ & $29.5 \pm 0.61$ \\
\hline & $\begin{array}{l}\text { Afternoon } \\
(14: 00 \mathrm{~h})\end{array}$ & $34.6 \pm 0.37$ & $29.1 \pm 0.43$ & $44.9 \pm 0.81$ & $24.4 \pm 1.27$ & $29.1 \pm 1.75$ & $39.9 \pm 0.63$ & $47.4 \pm 0.76$ \\
\hline
\end{tabular}

DBT-Dry Bulb Temperature; WBT- Wet Bulb Temperature; MinT-Minimum Temperature; MaxT-Maximum Temperature; RH-Relative Humidity; ATAmbient Temperature; PST-Pen Surface Temperature 


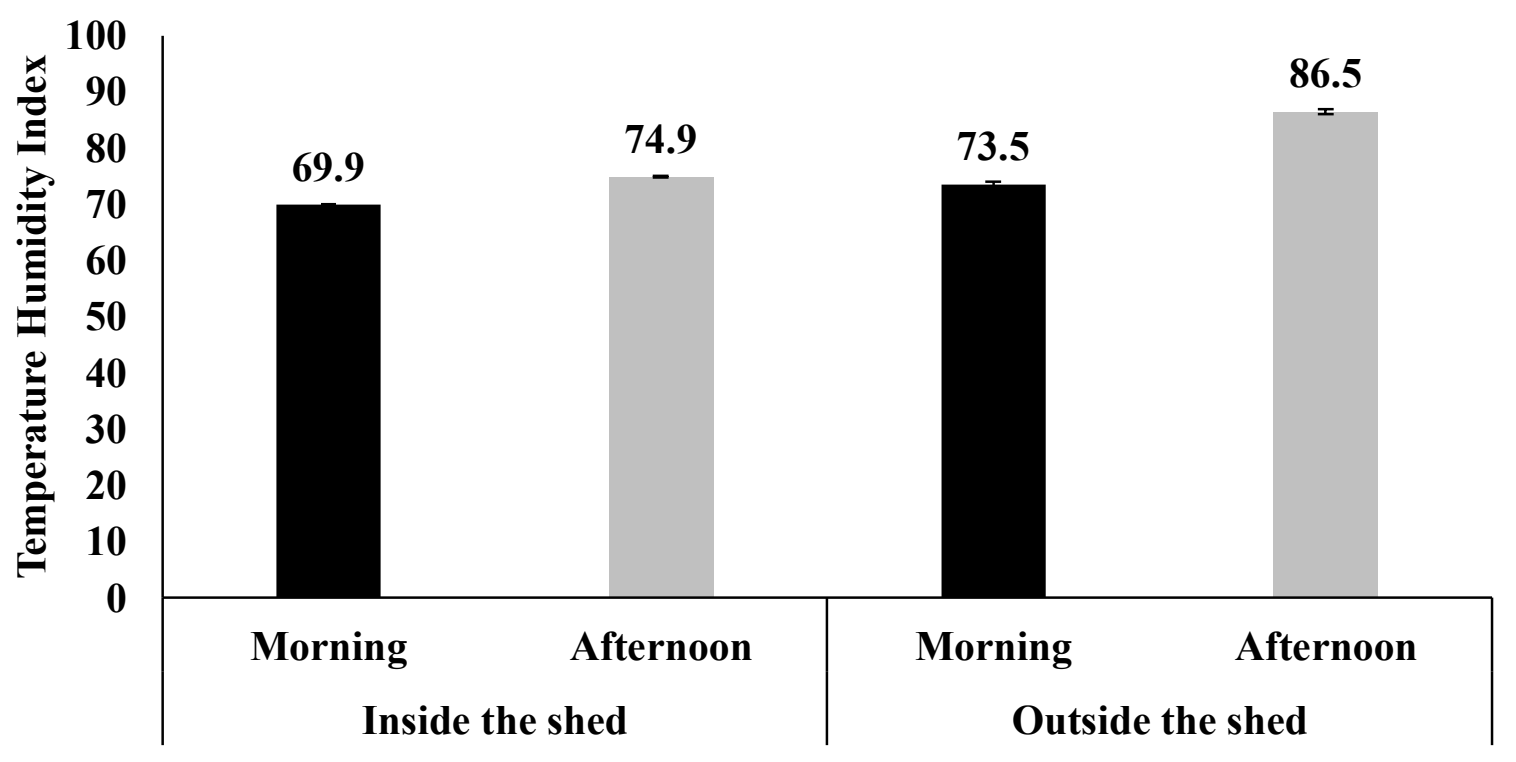

Figure 1 Average temperature humidity index (THI) both inside and outside the shed. The THI values were calculated as per method described by McDowell (1972). Accordingly the formula used was $\mathrm{THI}=0.72\left(\mathrm{~T}_{\mathrm{db}}+\mathrm{T}_{\mathrm{wb}}\right)+40.6$ where, $\mathrm{T}_{\mathrm{db}}=$ Dry bulb temperature in ${ }^{\circ} \mathrm{C}$; $\mathrm{T}_{\mathrm{wb}}=\mathrm{Wet}$ bulb temperature in ${ }^{\circ} \mathrm{C}$. The THI values 72 and less are considered comfortable; THI values between $75-78$ are considered stressful and THI above 78 considered extreme distress.

The Salem Black goat breed is an important Indian goat breed originated from the north-western part of Tamil Nadu, India. The breed owes its name from its place of origin (Salem) and color (black). The Salem Black breeds are completely black and found to be distributed in the Salem, Dharmapuri, Krishnagiri, Erode, Karur and Namakkal districts of Tamil Nadu. Generally, these goats are tall with a lean body. The ears are observed to be medium-long, leaf-like, and semi-pendulous. In adults, the bodyweight ranges between $35-39 \mathrm{~kg}$ and $25-30 \mathrm{~kg}$ for males and females respectively (Thiruvenkadan et al 2014).

Malabari (Tellichery) is a native Kerala breed, well known for its high milk yield, excellent growth rate, and adaptability to the hot humid conditions prevalent in the state (Alex et al 2013). The Malabari breed derived its name from its place of origin, the Malabar region of Kerala state. They are medium-sized dual-purpose breeds reared for both milk and meat with coat color ranging from white to admixtures and black (Alex et al 2013). The average body weight of adult males and female animals is 38.96 and $31.12 \mathrm{~kg}$ respectively.

The animals were housed in well-ventilated sheds made up of galvalume sheet roofing at the height $2.4 \mathrm{~m}$ and open from the side and maintained under proper hygienic conditions. Prophylactic measures against goat diseases like goat pox, peste des petits ruminants, enterotoxaemia, endo and ectoparasitic infestations were carried out as prescribed by the health calendar of the institute to ensure that the animals were in a healthy condition throughout the study.

\section{Technical program}

The study was conducted for 45 days between AprilMay 2017. Thirty six goats were randomly allocated into six groups of six animals each, OCON $(n=6$; Osmanabadi control), OHS ( $n=6$; Osmanabadi heat stress), MCON ( $n=6$; Malabari control), MHS ( $n=6$; Malabari heat stress), SCON $(n=6$; Salem Black control) and SHS ( $n=6$; Salem Black heat stress). The animals were stall-fed with a diet consisting of $60 \%$ roughage (Hybrid Napier) and $40 \%$ concentrate (Maize $36 \mathrm{~kg}$, wheat bran $37 \mathrm{~kg}$, soybean meal $25 \mathrm{~kg}$, mineral mixture $1.5 \mathrm{~kg}$, common salt $0.5 \mathrm{~kg} / 100 \mathrm{~kg}$ ). The OCON, MCON, and SCON animals were maintained in the shed while OHS, MHS, and SHS animals were exposed outside to summer heat stress between 10:00 $\mathrm{h}$ to $16: 00 \mathrm{~h}$ to expose to heat stress during the experimental period. The OCON, MCON, and SCON animals were fed and watered inside the shed while OHS, MHS, and SHS animals were fed and watered while they are exposed to summer heat stress in the outside environment.

\section{Blood collection and plasma separation}

Blood samples of $8 \mathrm{ml}$ were collected from the external jugular vein using 20 gauge sterilized needles and a plastic syringe in tubes with heparin anticoagulant (20 IU per ml of blood) (Sisco Research Laboratories pvt. Ltd, Bombay, India) at 11:00 $\mathrm{h}$ simultaneously from all the six groups at the fortnightly interval.

Plasma was separated from the blood using centrifugation technique, involving centrifugation at 3500 revolutions per minute (rpm) at room temperature for 20 minutes. The supernatant straw color plasma was separated using a sterile Pasteur pipette and stored in sterilized vials. The plasma was then preserved frozen at $-20^{\circ} \mathrm{C}$ till further 
analysis. The separated plasma samples were used to estimate all biochemical and endocrine parameters.

\section{Variables studied}

Blood biochemical variables

The biochemical parameters such as plasma glucose, plasma total protein, plasma albumin, plasma globulin, albumin/globulin (A/G) ratio, plasma total cholesterol, plasma triglycerides were estimated at fortnightly intervals while plasma urea, plasma urea nitrogen (PUN), aspartate aminotransferase (AST) and alanine aminotransferase (ALT) were estimated twice both at the start as well as the end of the experiment. Plasma glucose was estimated using Autospan kit, Surat, India, and all other biochemical variables were estimated using Asritha Diatech India Private (Pvt.) Limited (Ltd.) Telangana, India, using biospectrophotometer basic (Eppendorf, Hamburg, Germany).

Endocrine variables

Plasma aldosterone was estimated at fortnightly intervals. Plasma aldosterone (analytical sensitivity, 14 pg/ml; intra-assay and inter-assay coefficient of variations were 7.5 and $9.4 \%$, respectively). Plasma aldosterone was determined by enzyme-linked immunosorbent assay (ELISA) using a microplate reader (Thermo Scientific, Finland) by ELISA kits (LDN kit, Nordhorn, Germany).

\section{Statistical analysis}

The data were analyzed using a general linear model (GLM) repeated measurement analysis of variance (SPSS 18.0). Effect of fixed factors namely breeds (Osmanabadi, Malabari, Salem Black) and treatment (OCON, OHS, MCON, MHS, SCON, and SHS) was taken as between-subject factor and days (longitudinal time over which experiment was carried out; day 0 , day 15 , day 30 , and day 45) were taken as within-subject factor and also the interaction between breed, treatment and experimental days was analyzed on the various parameters studied. A comparison of means of the different subgroups was made by Duncan's multiple range tests as described by Kramer (1957). Further, the correlation coefficient between the THI and all phenotypic traits were established by Pearson's correlation coefficient test using SPSS (version 18.0) software. The $r$ values were used to establish the correlation association between THI and various blood biochemical and endocrine traits. Results are shown as mean \pm standard error (SE) and the significance level was set at $P<0.05$.

\section{Results}

Blood biochemical responses
The effects of heat stress on blood biochemical responses in Osmanabadi, Malabari, and Salem Black goats are described in Tables 2 and 3. Breed factor significantly influenced plasma glucose $(P<0.01)$, total protein $(P<0.01)$, albumin $(P<0.01)$, globulin $(P<0.01)$, triglycerides $(P<$ $0.01)$, AST $(P<0.05)$ and ALT $(P<0.05)$. However, heat stress treatment significantly influenced only plasma cholesterol $(P<0.05)$, triglycerides $(P<0.05)$, and AST $(P<$ $0.05)$. Heat stress significantly increased total plasma cholesterol and AST in MHS and OHS groups respectively. However, heat stress significantly reduced the plasma triglycerides concentration in both OHS and SHS groups. Further, experimental days significantly influenced plasma glucose $(P<0.01)$, total plasma cholesterol $P<0.01)$, plasma globulin $(P<0.01), \mathrm{A} / \mathrm{G}$ ratio $(P<0.05)$, urea $(P<0.01)$, PUN $(P<0.01)$, AST $(P<0.05)$ and ALT $(P<0.05)$. However, experimental days did not influence the total plasma protein, albumin, and triglycerides concentrations. Besides, among the biochemical variables, the interaction between breed, treatment, and experimental days influenced $(P<0.05)$ only plasma AST concentration. Moreover, no correlation association was established between THI and any of the biochemical variables in the study (Tables 4 and 5).

\section{Endocrine responses}

The effects of heat stress on plasma aldosterone concentration in Osmanabadi, Malabari and Salem Black goats are presented in table 4. Plasma aldosterone showed significant variation for both breeds $(P<0.01)$ as well as heat stress treatment $(P<0.05)$. Heat stress significantly $(P<0.05)$ reduced the plasma aldosterone level only in Malabari goats (Figure 2). Further, the experimental days also significantly $(P$ $<0.01)$ influenced plasma aldosterone in the study. However, the interaction between breed, treatment, and experimental days did not influence plasma aldosterone level. In addition, a strong negative correlation $(\mathrm{r}=-0.34 ; \mathrm{P}<0.01)$ was established between THI and plasma aldosterone concentration.

\section{Discussion}

Generally, the blood metabolic profile indicates the health and nutritional status of the livestock (Calamari et al 2016). Exposure of the animals to heat stress environments significantly alter their general blood biochemical status (Banerjee et al 2015; Singh et al 2016). The mean concentration values for the glucose showed breed differences with significantly higher values in Osmanabadi and Malabari goat breeds compared to the Salem Black breeds. The results obtained in the study were in accordance with a previous experiment conducted by Mohammed et al (2016) where they also showed breed variations regarding the glucose level in different goat breeds. The non-significant change in the 
glucose level in all the three breeds for the heat stress treatment could be attributed to their adaptive potential for these breeds are well known for their survival in the adverse environmental conditions in their native tracks (Banerjee et al
2015; Shaji et al 2017). Similar results of the non-significant variations of glucose concentration during heat stress were also reported in heat-tolerant indigenous sheep and goats (Singh et al 2016; Banerjee et al 2015; Shaji et al 2017).

Table 2 Effect of heat stress on blood biochemical responses in Osmanabadi, Malabari and Salem Black goat breeds.

\begin{tabular}{|c|c|c|c|c|c|c|c|c|c|c|c|}
\hline \multirow[t]{2}{*}{ Attributes } & \multirow[t]{2}{*}{ Days } & \multicolumn{6}{|c|}{ Treatments } & \multicolumn{4}{|c|}{ Effects } \\
\hline & & OCON & OHS & $\mathrm{MCON}$ & MHS & SCON & SHS & Breed & TRT & DAY & $\begin{array}{c}\text { Breed }^{*} \mathrm{TRT}^{*} \\
\text { DAY }\end{array}$ \\
\hline \multirow[t]{7}{*}{ Plasma Glucose (mg/dL) } & 0 & 54.95 & 54.93 & 52.76 & 55.41 & 51.30 & 51.49 & $* *$ & NS & $* *$ & NS \\
\hline & 15 & 66.67 & 69.63 & 60.11 & 74.56 & 68.03 & 59.09 & & & & \\
\hline & 30 & 52.63 & 54.46 & 50.26 & 51.18 & 43.83 & 37.14 & & & & \\
\hline & 45 & 57.17 & 63.52 & 45.40 & 52.94 & 48.97 & 44.21 & & & & \\
\hline & Mean & $57.85^{\mathrm{ab}}$ & $60.64^{\mathrm{a}}$ & $52.13^{b c}$ & $58.52^{\mathrm{ab}}$ & $53.03^{\mathrm{abc}}$ & $47.98^{c}$ & & & & \\
\hline & Pooled & \pm 2.48 & \pm 2.48 & \pm 2.48 & \pm 2.48 & \pm 2.48 & \pm 2.48 & & & & \\
\hline & SE & & & & & & & & & & \\
\hline \multirow{7}{*}{$\begin{array}{l}\text { Plasma Total Cholesterol } \\
(\mathrm{mg} / \mathrm{dL})\end{array}$} & 0 & 65.06 & 59.80 & 58.50 & 57.05 & 58.65 & 58.33 & NS & * & $* *$ & NS \\
\hline & 15 & 116.03 & 86.86 & 83.97 & 117.95 & 109.04 & 103.21 & & & & \\
\hline & 30 & 76.58 & 78.97 & 70.26 & 83.91 & 100.71 & 97.56 & & & & \\
\hline & 45 & 133.65 & 117.31 & 76.28 & 100.96 & 64.74 & 54.81 & & & & \\
\hline & Mean & $97.83^{\mathrm{a}}$ & $85.73^{\mathrm{abc}}$ & $72.25^{\mathrm{c}}$ & $89.97^{\mathrm{ab}}$ & $83.29^{\mathrm{abc}}$ & $78.48^{\mathrm{bc}}$ & & & & \\
\hline & Pooled & \pm 4.96 & \pm 4.96 & \pm 4.96 & \pm 4.96 & \pm 4.96 & \pm 4.96 & & & & \\
\hline & SE & & & & & & & & & & \\
\hline \multirow{7}{*}{$\begin{array}{l}\text { Plasma Total Protein } \\
(\mathrm{g} / \mathrm{dL})\end{array}$} & 0 & 5.82 & 5.95 & 5.40 & 5.83 & 5.91 & 5.87 & $* *$ & NS & NS & NS \\
\hline & 15 & 9.42 & 8.72 & 7.50 & 8.65 & 8.56 & 7.93 & & & & \\
\hline & 30 & 6.91 & 6.95 & 6.43 & 7.82 & 6.78 & 6.21 & & & & \\
\hline & 45 & 8.31 & 7.97 & 7.27 & 6.06 & 6.12 & 4.67 & & & & \\
\hline & Mean & $7.62^{\mathrm{a}}$ & $7.40^{\mathrm{ab}}$ & $6.65^{\mathrm{bc}}$ & $7.09^{\mathrm{ab}}$ & $6.84^{\mathrm{abc}}$ & $6.17^{\mathrm{c}}$ & & & & \\
\hline & Pooled & \pm 0.26 & \pm 0.26 & \pm 0.26 & \pm 0.26 & \pm 0.26 & \pm 0.26 & & & & \\
\hline & $\mathrm{SE}$ & & & & & & & & & & \\
\hline \multirow{7}{*}{$\begin{array}{l}\text { Plasma Albumin } \\
(\mathrm{g} / \mathrm{dL})\end{array}$} & 0 & 4.24 & 4.43 & 3.06 & 3.19 & 4.01 & 3.92 & $* *$ & NS & NS & NS \\
\hline & 15 & 6.67 & 6.49 & 3.80 & 4.83 & 5.83 & 5.34 & & & & \\
\hline & 30 & 4.40 & 4.60 & 3.54 & 3.61 & 4.28 & 4.13 & & & & \\
\hline & 45 & 5.73 & 5.72 & 3.88 & 3.35 & 3.39 & 3.41 & & & & \\
\hline & Mean & $5.26^{\mathrm{a}}$ & $5.31^{\mathrm{a}}$ & $3.57^{\mathrm{d}}$ & $3.74^{\mathrm{cd}}$ & $4.37^{\mathrm{b}}$ & $4.20^{\mathrm{bc}}$ & & & & \\
\hline & Pooled & \pm 0.18 & \pm 0.18 & \pm 0.18 & \pm 0.18 & \pm 0.18 & \pm 0.18 & & & & \\
\hline & $\mathrm{SE}$ & & & & & & & & & & \\
\hline \multirow[t]{7}{*}{ Plasma Globulin (g/dL) } & 0 & 2.42 & 2.18 & 2.86 & 3.22 & 2.62 & 2.74 & $* *$ & NS & $* *$ & NS \\
\hline & 15 & 2.75 & 2.23 & 3.70 & 3.83 & 2.73 & 2.60 & & & & \\
\hline & 30 & 2.50 & 2.36 & 2.89 & 4.20 & 2.50 & 2.09 & & & & \\
\hline & 45 & 2.58 & 2.25 & 3.39 & 2.71 & 1.07 & 1.26 & & & & \\
\hline & Mean & $2.56^{\mathrm{bc}}$ & $2.26^{\mathrm{c}}$ & $3.21^{\mathrm{ab}}$ & $3.50^{\mathrm{a}}$ & $2.23^{\mathrm{c}}$ & $2.17^{\mathrm{c}}$ & & & & \\
\hline & Pooled & \pm 0.25 & \pm 0.25 & \pm 0.25 & \pm 0.25 & \pm 0.25 & \pm 0.25 & & & & \\
\hline & $\mathrm{SE}$ & & & & & & & & & & \\
\hline \multirow[t]{7}{*}{ Albumin/Globulin Ratio } & 0 & 1.82 & 2.05 & 1.18 & 1.02 & 1.59 & 1.64 & NS & NS & $*$ & NS \\
\hline & 15 & 2.74 & 4.44 & 2.44 & 1.34 & 2.28 & 2.20 & & & & \\
\hline & 30 & 2.00 & 2.22 & 1.56 & 0.94 & 2.28 & 2.31 & & & & \\
\hline & 45 & 2.36 & 2.65 & 1.25 & 3.74 & 4.43 & 3.25 & & & & \\
\hline & Mean & $2.23^{\mathrm{a}}$ & $2.84^{\mathrm{a}}$ & $1.60^{\mathrm{a}}$ & $1.76^{\mathrm{a}}$ & $2.65^{\mathrm{a}}$ & $2.35^{\mathrm{a}}$ & & & & \\
\hline & Pooled & \pm 0.46 & \pm 0.46 & \pm 0.46 & \pm 0.46 & \pm 0.46 & \pm 0.46 & & & & \\
\hline & $\mathrm{SE}$ & & & & & & & & & & \\
\hline \multirow{6}{*}{$\begin{array}{l}\text { Plasma Triglycerides } \\
(\mathrm{mg} / \mathrm{dL})\end{array}$} & 0 & 8.04 & 8.22 & 8.57 & 9.29 & 8.56 & 8.41 & $* *$ & $*$ & NS & NS \\
\hline & 15 & 9.93 & 6.72 & 9.61 & 10.15 & 8.55 & 6.93 & & & & \\
\hline & 30 & 8.71 & 6.71 & 8.71 & 10.61 & 8.51 & 6.86 & & & & \\
\hline & 45 & 9.13 & 6.49 & 9.51 & 10.29 & 8.69 & 6.39 & & & & \\
\hline & Mean & $8.95^{\mathrm{ab}}$ & $7.04^{\mathrm{c}}$ & $9.1^{\mathrm{a}}$ & $10.09^{\mathrm{ab}}$ & $8.58^{b}$ & $7.15^{\mathrm{c}}$ & & & & \\
\hline & $\begin{array}{l}\text { Pooled } \\
\text { SF }\end{array}$ & \pm 0.40 & \pm 0.40 & \pm 0.40 & \pm 0.40 & \pm 0.40 & \pm 0.40 & & & & \\
\hline
\end{tabular}

OCON, Osmanabadi control; OHS, Osmanabadi heat stress; MCON, Malabari control; MHS, Malabari heat stress; SCON, Salem Black control; SHS, Salem Black heat stress; TRT, treatment; Breed*TRT* Breed, treatment and day interaction; SE-Standard Error

${ }^{*} P<0.01 ; * P<0.05 ; \mathrm{NS}$, non-significant 
Plasma cholesterol showed significant variation among the breeds for heat stress treatment. In addition the analysis pertaining to the effect of heat stress within the breed indicated that only Malabari breed showed significantly higher cholesterol level in the heat stress group as compared to their control group. This indicates that on a comparative basis Malabari breed was more sensitive to the heat stress challenges imposed in the study. The higher cholesterol level in MHS goats could be an effort by this breed to support hepatic gluconeogenesis by mobilizing the fat reserves to maintain the additional glucose supply for the adaptation processes (Sejian et al 2013). Further, the increased cholesterol level in MHS goats may also be attributed to the requirement of higher cortisol level to counter the heat stress level given the fact that cholesterol is the precursor material for cortisol synthesis (Ghani et al 2016). These explanations pertaining to cholesterol levels were supported by the findings of Sejian et al (2013) in heat-stressed indigenous Malpura sheep. However, there are also reports indicating decreased cholesterol concentration in ruminants during the summer season (Singh et al 2016; Ocak and Guey 2010). Further, the non-significant variation of cholesterol level between the SCON and SHS groups in Salem Black breed was similar to the result obtained for the local Osmanabadi breed.

The highly significant difference in breed factor for total protein, albumin, and globulin in the study indicates the different potential of these breeds to use the protein sources efficiently for supporting the adaptive processes to tropical climate. Generally, concentrations of total protein and albumin are used as indices for nutritional status in goats (Attia et al 2016). The plasma protein, albumin, globulin, and $\mathrm{A} / \mathrm{G}$ ratio did not show significant variation between groups for the heat stress treatment. However, a significant increase in these parameters was reported in Baladi, Zarabi goats during short term exposure to heat stress (Helal et al 2010). The non-significant change in these variables suggests the significant adaptive nature of these indigenous goat breeds to heat stress challenges as they were able to maintain their nutritional status throughout the study.

Table 3 Effect of heat stress on blood biochemical responses in Osmanabadi, Malabari and Salem Black goat breeds.

\begin{tabular}{|c|c|c|c|c|c|c|c|c|c|c|c|}
\hline \multirow[t]{2}{*}{ Attributes } & \multirow[t]{2}{*}{ Days } & \multicolumn{6}{|c|}{ Treatments } & \multicolumn{4}{|c|}{ Effects } \\
\hline & & OCON & OHS & MCON & MHS & SCON & SHS & Breed & TRT & $\overline{D A Y}$ & $\begin{array}{l}\text { Breed* } \\
\text { TRT * } \\
\text { DAY }\end{array}$ \\
\hline $\begin{array}{c}\text { Plasma Urea } \\
(\mathrm{mg} / \mathrm{dL})\end{array}$ & $\begin{array}{l}0 \\
45 \\
\text { Mean } \\
\text { Pooled } \\
\text { SE }\end{array}$ & $\begin{array}{l}42.17 \\
59.95 \\
51.06^{\mathrm{a}} \\
\pm 3.09\end{array}$ & $\begin{array}{l}38.88 \\
63.01 \\
50.94^{\mathrm{a}} \\
\pm 3.09\end{array}$ & $\begin{array}{l}44.02 \\
50.28 \\
47.15^{\mathrm{a}} \\
\pm 3.09\end{array}$ & $\begin{array}{l}43.29 \\
66.67 \\
54.98^{\mathrm{a}} \\
\pm 3.09\end{array}$ & $\begin{array}{l}50.08 \\
47.64 \\
48.86^{\mathrm{a}} \\
\pm 3.09\end{array}$ & $\begin{array}{l}49.32 \\
43.42 \\
46.37^{\mathrm{a}} \\
\pm 3.09\end{array}$ & NS & NS & $* *$ & NS \\
\hline PUN (mg/dL) & $\begin{array}{l}0 \\
45 \\
\text { Mean } \\
\text { Pooled } \\
\text { SE } \\
\end{array}$ & $\begin{array}{l}19.69 \\
28.00 \\
23.85^{\mathrm{a}} \\
\pm 1.44\end{array}$ & $\begin{array}{l}18.16 \\
29.43 \\
23.79^{\mathrm{a}} \\
\pm 1.44\end{array}$ & $\begin{array}{l}20.56 \\
23.48 \\
22.02^{\mathrm{a}} \\
\pm 1.44\end{array}$ & $\begin{array}{l}20.22 \\
31.13 \\
25.68^{\mathrm{a}} \\
\pm 1.44\end{array}$ & $\begin{array}{l}23.39 \\
22.25 \\
22.82^{\mathrm{a}} \\
\pm 1.44\end{array}$ & $\begin{array}{l}23.03 \\
20.28 \\
21.65^{\mathrm{a}} \\
\pm 1.44\end{array}$ & NS & NS & $* *$ & NS \\
\hline AST (IU/L) & $\begin{array}{l}0 \\
45 \\
\text { Mean } \\
\text { Pooled } \\
\text { SE } \\
\end{array}$ & $\begin{array}{l}65.90 \\
76.02 \\
70.96^{\mathrm{b}} \\
\pm 2.17\end{array}$ & $\begin{array}{l}66.33 \\
93.02 \\
79.67^{\mathrm{a}} \\
\pm 2.17\end{array}$ & $\begin{array}{l}65.31 \\
70.30 \\
67.80^{\mathrm{b}} \\
\pm 2.17\end{array}$ & $\begin{array}{l}68.72 \\
79.00 \\
73.86^{\mathrm{ab}} \\
\pm 2.17\end{array}$ & $\begin{array}{l}67.85 \\
72.31 \\
70.08^{\mathrm{b}} \\
\pm 2.17\end{array}$ & $\begin{array}{l}69.44 \\
68.14 \\
68.79^{\mathrm{b}} \\
\pm 2.17\end{array}$ & $*$ & $*$ & ** & * \\
\hline ALT (IU/L) & $\begin{array}{l}0 \\
45 \\
\text { Mean } \\
\text { Pooled } \\
\text { SE }\end{array}$ & $\begin{array}{l}16.69 \\
15.04 \\
15.87^{\text {ab }} \\
\pm 0.77\end{array}$ & $\begin{array}{l}16.14 \\
14.85 \\
15.50^{\mathrm{ab}} \\
\pm 0.77\end{array}$ & $\begin{array}{l}17.08 \\
14.66 \\
15.87^{\mathrm{ab}} \\
\pm 0.77\end{array}$ & $\begin{array}{l}17.14 \\
17.37 \\
17.26^{\mathrm{a}} \\
\pm 0.77\end{array}$ & $\begin{array}{l}15.06 \\
14.37 \\
14.71^{\mathrm{b}} \\
\pm 0.77\end{array}$ & $\begin{array}{l}15.85 \\
13.08 \\
14.46^{\mathrm{b}} \\
\pm 0.77\end{array}$ & $*$ & NS & $*$ & NS \\
\hline $\begin{array}{l}\text { Aldosterone } \\
(\mathrm{pg} / \mathrm{mL})\end{array}$ & $\begin{array}{l}0 \\
15 \\
30 \\
45 \\
\text { Mean } \\
\text { Pooled } \\
\text { SE }\end{array}$ & $\begin{array}{l}51.08 \\
68.04 \\
40.93 \\
53.72 \\
53.44^{\text {cd }} \\
\pm 10.55\end{array}$ & $\begin{array}{l}48.34 \\
37.80 \\
33.12 \\
59.72 \\
44.74^{\mathrm{d}} \\
\pm 10.55\end{array}$ & $\begin{array}{l}109.03 \\
113.36 \\
111.78 \\
100.73 \\
108.72^{\mathrm{a}} \\
\pm 10.55\end{array}$ & $\begin{array}{l}109.10 \\
85.57 \\
39.97 \\
65.98 \\
75.16^{\text {bcd }} \\
\pm 10.55\end{array}$ & $\begin{array}{l}114.81 \\
114.35 \\
89.98 \\
97.60 \\
104.1^{\mathrm{ab}} \\
\pm 10.55\end{array}$ & $\begin{array}{l}110.38 \\
87.46 \\
64.19 \\
67.27 \\
82.32^{\mathrm{abc}} \\
\pm 10.55\end{array}$ & $* *$ & * & $* *$ & NS \\
\hline
\end{tabular}

OCON, Osmanabadi control; OHS, Osmanabadi heat stress; MCON, Malabari control; MHS, Malabari heat stress; SCON, Salem Black control; SHS, Salem Black heat stress; TRT, treatment; Breed*TRT* Breed, treatment and day interaction; PUN, Plasma Urea Nitrogen; AST, Aspartate aminotransferase; ALT, Alanine aminotransferase; SE-Standard Error

$* * P<0.01 ; * P<0.05 ; \mathrm{NS}$, non-significant 
The plasma triglycerides showed significant variation within both Osmanabadi and Salem Black breeds for heat stress treatment with lower values in OHS and SHS compared to their respective control groups. Similar result of significantly reduced triglyceride level was also reported in heat-stressed goats, sheep, and cattle (Pandey et al 2012; Singh et al 2016; Omran et al 2011). The lower triglyceride level in OHS and SHS group goats could be attributed to the higher hepatic gluconeogenesis to meet the enhanced energy demand during heat stress conditions (Dias e Silva et al 2016). Further, the non-significant effect of breed and heat stress treatment on both plasma urea and PUN indicates the coping ability of all three breeds without relying on these parameters to support the adaptation processes. Similar results of the nonsignificant change of urea and PUN during heat stress in male animals of Osmanabadi breed was also reported by Shaji et al (2017).

The AST and ALT are generally recognized as indicators for adaptive capability in livestock (Gupta et al 2013). The AST level was found to be significantly higher in OHS compared to OCON, while within Salem black and Malabari breeds, non-significant variations were observed. The findings were similar to the observations in Sirohi and Barbari goat breeds where these animals also did not show a significant difference for the AST level during summer (Banerjee et al 2015). However, significantly higher AST concentration was also reported in ruminants exposed to heat stress conditions (Rathwa et al 2017; Gupta et al 2013). The significantly higher AST level in OHS could be attributed to the increased hepatic gluconeogenesis which may lead to hepatic damage due to the deleterious effects of heat stress (Rathwa et al 2017). Further, the significantly higher AST only in OHS might be correlated to the sensitivity of this breed to heat stress as this is the breed that was native to the locality where the study was conducted. The non-significant influence of heat stress on both MHS and SHS could be attributed to the fact that these breeds are brought from their original native tract of the much higher magnitude of heat stress to the current locality in the study. Therefore, the AST did not increase in the heat stress groups of these two breeds due to the lower magnitude of heat stress in the current location as compared to their native agro-ecological zone. Additionally, AST is the only biochemical parameter which was significantly influenced by interaction between breed, treatment and experimental days. This indicates the role of AST in assessing the coping ability of indigenous goat breeds to heat stress. In addition, the ALT level did not show significant variations in all three breeds for heat stress treatment. However, higher activity of ALT was reported by Sharma and Kataria (2011), Banerjee et al (2015) in heat-stressed goats. This difference could be attributed to the differences in the magnitude of heat stress between the studies. The non-significant influence of breed, treatment and experimental days interaction on all the biochemical variables indicates that the non-reliability of these breeds on these variables to cope to heat stress environment. Further, the non-significant association between $\mathrm{THI}$ and all the biochemical variables supports this argument.

Table 4 Correlation association between THI and blood biochemical responses.

\begin{tabular}{lcccccc}
\hline & THI & Glucose & TP & Albumin & Globulin & A/G ratio \\
\hline THI & - & & & & & \\
Glucose & 0.06 & - & - & & \\
TP & -0.08 & $0.35^{* *}$ & $0.72^{* *}$ & - & - & - \\
Albumin & -0.01 & $0.47^{* *}$ & $0.64^{* *}$ & -0.01 & & -0.13 \\
Globulin & -0.03 & 0.00 & $-0.29^{*}$ & 0.14 & $-0.63^{* *}$ & - \\
A/G ratio & 0.04 & 0.15 & $0.46^{* *}$ & $0.43^{* *}$ & $0.22^{*}$ & -0.03 \\
TC & 0.02 & $0.35^{* *}$ & 0.09 & -0.09 & $0.21^{*}$ & 0.04 \\
TG & -0.26 & 0.09 & & & \\
\hline
\end{tabular}

THI- Temperature humidity index; TP- Total protein; A/G ratio- Albumin/globulin ratio; TC- Total cholesterol; TG- Total triglycerides

**Indicates statistical significance at $P<0.01$; Indicates statistical significance at $P<0.05$

It is a general observation in many species that when the animals are subjected to heat stress it causes severe dehydration resulting in increased renin-angiotensinaldosterone response (Wittenberg et al 1986; Olsson and Dahlborn 1989; Shaji et al 2017). However, when the heatstressed animals get access to water sources or in other words if they are rehydrated there are further increase in the renin response which is usually not accompanied by elevated plasma aldosterone concentration (Olsson and Dahlborn 1989;
Wittenberg et al 1986). Similarly in the current study in Malabari breed, the level of plasma aldosterone was significantly lower in heat-stressed animals which had ad libitum access to water. The non-significant influence of heat stress on plasma aldosterone concentration in both Osmanabadi and Salem Black could be attributed again to their extreme adaptive capability in maintaining the water and electrolyte balance. Therefore, the non-significant influence of heat stress on plasma aldosterone in Osmanabadi and Salem 
breeds could prove their superior adaptive capability over Malabari breed goats. However, in another study in Osmanabadi male goats, Shaji et al (2017) reported significantly higher plasma aldosterone concentration in the heat-stressed group. This difference in aldosterone concentration between the studies could be attributed to the sexual difference as the other study was in the male animals.

Table 5 Correlation association between THI and blood biochemical responses.

\begin{tabular}{lcccc}
\hline & THI & Urea & PUN & AST \\
\hline THI & - & & & \\
Urea & 0.17 & - & & \\
PUN & 0.17 & $1.00^{* *}$ & - & \\
AST & 0.30 & $0.53^{* *}$ & $0.53^{* *}$ & - \\
ALT & 0.07 & 0.23 & 0.23 & -0.03
\end{tabular}

THI- temperature humidity index; PUN- plasma urea nitrogen; ASTaspartate aminotransferase; ALT - alanine aminotransferase

**Indicates statistical significance at $P<0.01$
It is a general observation that indigenous breeds rely more on the panting mechanism rather than sweating and this imparts an exclusive ability to these animals to maintain water and electrolyte balance (Alamer 2003). Osmanabadi and Salem Black are also indigenous breeds and well known for their adaptive capacity to heat stress and both these breeds relied mostly on the respiratory evaporative cooling mechanism to cope with heat stress. This could be the reason for the non-significant influence of heat stress on the plasma aldosterone concentration in these breeds as they tried to keep intact their electrolyte balance indicating the non-requirement for this hormone. This finding could be supported by the fact that these animals had access to water ad libitum and they were provided with a balanced ration containing mineral and salt supplementation. Further, the non-significant influence of different factors interaction on plasma aldosterone concentration indicates that these effects persisted throughout the study period. In addition, the negative correlation for aldosterone respectively with THI indicates the reliable significance of these variables in assessing the thermo-tolerant ability of indigenous goats.

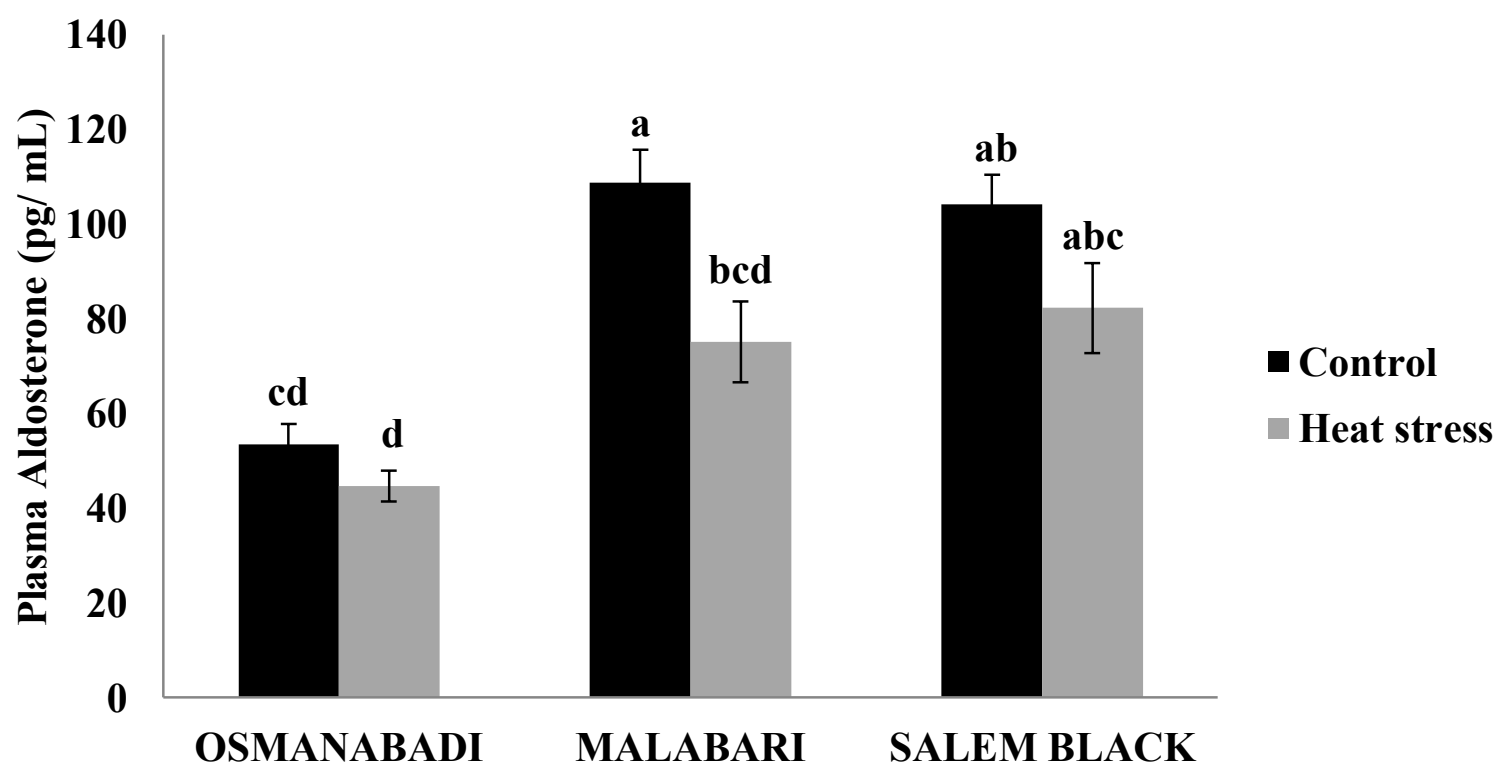

Figure 2 Effect of heat stress on plasma aldosterone concentration in Osmanabadi, Malabari and Salem black goats. Values bearing different superscripts differed significantly at $P<0.05$.

\section{Conclusions}

The finding from the study indicates the non-reliability of all three breeds on the biochemical response to adapt to the heat stress challenges. Further, the results obtained for various variables indicated that the Malabari breed goats experienced a higher magnitude of heat stress as compared to both Osmanabadi and Salem Black breeds. Therefore, the shifting of Malabari breed from the extremely hot and humid environment in their native tract to the current experimental location with heat stress of much lower magnitude did not prove advantageous in terms of its adaptive potential. However, significantly less influence of heat stress on the majority of the variables studied in Salem Black breed and the efficiency of this breed in maintaining the adaptive potential more or less similar to the Osmanabadi breed indicated the superior ability of this breed to cope to varied tropical environment. Therefore shifting of Salem Black breed may yield beneficial effects in sustaining their production in the different agro-ecological zone. However, future studies are 
warranted to further test the thermo-tolerant efficiency of this breed in other locations.

\section{Acknowledgements}

The authors are more grateful to the Director, ICARNational Institute of Animal Nutrition and Physiology for providing the research facilities to complete this study. The authors also highly thankful to the Indian Council of Agricultural Research (ICAR) for providing the funding for this research work.

\section{Conflict of Interest}

The authors declare that there is no conflict of interest for this manuscript.

\section{References}

Alamer MA (2003) Heat tolerance of local goat breeds in Saudi Arabia. Arab Gulf Journal of Science and Research 21:210-216.

Alex R, Cheemani RK, Thomas N (2013) Returns and determinants of technical efficiency in small-scale Malabari goat production units in Kerala, India. Tropical Animal Health and Production 45:16631668.

Attia NES (2016) Physiological, hematological and biochemical alterations in heat stressed goats. Benha Veterinary Medicine Journal 31:56-62.

Banerjee D, Upadhyay RC, Chaudhary UB, Kumar R, Singh S, Ashutosh Das KT, De S (2015) Seasonal variations in physiobiochemical profiles of Indian goats in the paradigm of hot and cold climate. Biological Rhythm Research 46:221-236.

Calamari L, Ferrari A, Minuti A, Trevisi E (2016) Assessment of the main plasma parameters included in a metabolic profile of dairy cow based on Fourier Transform mid-infrared spectroscopy: preliminary results. BMC Veterinary Research 12:4.

Deokar DK, Lawar VS, Ulmek BR (2006) Morphological characteristics of Osmanabadi goats. Indian Journal of Small Ruminants 12:13-15.

Dias e Silva TP, da Costa Torreão JN, Marques CAT, de Araújo MJ, Bezerra LR, Kumar Dhanasekaran D, Sejian V (2016) Effect of multiple stress factors (thermal, nutritional and pregnancy type) on adaptive capability of native ewes under semi-arid environment. Journal of Thermal Biology 59:39-46.

FAO (2015) Climate change and food systems: global assessments and implications for food security and trade. Food Agriculture Organization of the United Nations (FAO). Available in: http://www.fao.org/3/a-i4332e.pdf

Ghani MU, Ahmad I, Ahmad N, Ijaz N, Mehfooz A (2016) Hematology, Serum Total Cholesterol and Thyroid Hormone Concentrations in Cyclic and Acyclic Nili-Ravi Buffaloes. Pakistan Veterinary Journal 37:31-34.

Gupta M, Kumar S, Dangi SS, Jangir BL (2013) Physiological, biochemical and molecular responses to thermal stress in goats. International Journal of Livestock Research 3:27-38.

Habibu B, Kawu MU, Makun HJ, Aluwong T, Yaqub LS (2016) Seasonal variation in body mass index, cardinal physiological variables and serum thyroid hormones profiles in relation to susceptibility to thermal stress in goat kids. Small Ruminant Research 145:20-27.

Helal A, Hashem ALS, Abdel-Fattah MS, El-Shaer (2010) Effects of heat stress on coat charecteristics and physiological responses of balady and Damascus goat in Sinai Egypt. American- Eurasian Journal of Agriculture and Environmental Science 7:60-69.

Kramer CY (1957) Extension of multiple range tests to group correlated adjusted means. Biometrics 13:13-18.

McDowell RE (1972) Improvement of livestock production in warm climate. WH Freeman and Co, San Fransisco, USA.

Mlambo V, Mapiye C (2015) Towards household food and nutrition security in semi-arid areas: What role for condensed tannin-rich ruminant feedstuffs? Food Research International 76:953-961.

Mohammed SA, Razzaque MA, Omar AE, Albert S, Al-Gallaf WM (2016) Biochemical and hematological profile of different breeds of goat maintained under intensive production system. African Journal of Biotechnology 15:1253-1257.

Mpofu TJ, Ginindza MM, Siwendu NA, Nephawe, KA, Mtileni, BJ (2017) Effect of agro-ecological zone, season of birth and sex on preweaning performance of Nguni calves in Limpopo Province, South Africa. Tropical Animal Health and Production 49:187-194.

Ocak S, Guey O (2010) Physiological responses and some blood parameters of bucks under Mediterranean climate conditions. Anadolu Journal of Agricultural Sciences 25:113-119.

Olsson K, Dahlborn K (1989) Fluid balance during heat stress in lactating goats. Experimental Physiology 74:645-659.

Omran FI, Ashour G, Youssef M M, Shafie MM (2011) Responses of hematology, blood metabolites, mineral ions and hormonal profile to heat stress for Egyptian buffalo-calves. Egyptian Journal of Agricultural Research 89:1129-1138.

Pandey N, Kataria N, Kataria AK, Joshi A (2012) Ambient stress associated variations in metabolic responses of Marwari goat of arid tracts in India. Journal of Stress Physiology and Biochemistry 8:120127.

Rathwa SD, Vasava AA, Pathan MM, Madhira SP, Patel YG, Pande AM (2017) Effect of season on physiological, biochemical, hormonal, and oxidative stress parameters of indigenous sheep. Veterinary World 10:650-654.

Rojas-Downing MM, Nejadhashemi AP, Harrigan T, Woznicki SA (2017) Climate change and livestock: impacts, adaptation, and mitigation. Climate Risk Management 16:145-163.

Sejian V, Indu S, Naqvi SMK (2013) Impact of short term exposure to different environmental temperature on the blood biochemical and endocrine responses of Malpura ewes under semi-arid tropical environment. Indian Journal of Animal Science 83:1155-1160.

Shaji S, Sejian V, Bagath M, Manjunathareddy GB, Kurien EK, Varma G, Bhatta R (2017) Summer season related heat and nutritional stresses on the adaptive capability of goats based on blood biochemical response and hepatic HSP70 gene expression. Biological Rhythm Research 48:65-83.

Sharma AK, Kataria N (2011) Effect of extreme hot climate on liver and serum enzymes in Marwari goats. Indian Journal of Animal Science 81:293-295.

Silanikove N, Koluman N (2015) Impact of climate change on the dairy industry in temperate zones: predications on the overall negative impact and on the positive role of dairy goats in adaptation to earth warming. Small Ruminant Research 123:27-34. 
Singh KM, Singh S, Ganguly I, Ganguly A, Nachiappan RK, Chopra A, Narula HK (2016) Evaluation of Indian sheep breeds of arid zone under heat stress condition. Small Ruminant Research 141:113-117.

Thiruvenkadan AK, Jayakumar V, Kathiravan P, Saravanan R (2014) Genetic architecture and bottleneck analyses of Salem Black goat breed based on microsatellite markers. Veterinary World 7:733-737.
Thornton PK (2010) Livestock production: recent trends, future prospects. Philosophical Transactions of the Royal Society of London B Biological Science 365:2853-2867.

Wittenberg C, Choshniak I, Shkolnik A, Thurau K, Rosenfeld J (1986) Effect of dehydration and rapid rehydration on renal function and on plasma renin and aldosterone levels in the black Bedouin goat. Pflügers Archiv: European Journal of Physiology 406:405-408. 